\title{
The Southern African unipolarity
}

\author{
Luis L. Schenoni \\ Political Science Department, University of Notre Dame, Notre Dame, IN, United States
}

\begin{abstract}
Despite the tectonic changes that have taken place in Southern Africa since the demise of apartheid, South Africa is still widely considered a hegemonic regional power by scholars, practitioners and pundits. This article challenges this interpretation, asserting that both Pretoria's foreign policy and that of its neighbours fit the concept of regional unipolarity with more precision. Since the early 1990s, South Africa has pursued leadership within binding regional institutions and invested resources in order to reinforce the sovereignty of second-tier states such as Angola, Mozambique and Zimbabwe, which have in turn disputed its diplomatic and military primacy, achieving impressive results. This behaviour is characteristic of unipoles rather than hegemons. In this article I revisit the evolution of South African relations with its more proximate neighbours in a transition from hegemony (1961-1990) to unipolarity. I start by defining both concepts and clarifying the behaviours that regional powers and small states are expected to have under hegemonic and unipolar settings. Then, I examine inter-state relations in the region, showing that the concept of unipolarity best describes power distribution and best predicts foreign policy in Southern Africa since the 1990s. Finally, I show that this exercise in concept rectification illuminates comparisons with other regional unipoles, and provides a useful framework to forecast the consequences of an eventual Southern African bipolarity, if Angola continues to catch up.
\end{abstract}

\section{KEYWORDS}

Unipolarity; hegemony; Southern Africa; South

African foreign policy

\section{Regional hegemony and its limits}

Academics and practitioners alike continue to refer to South Africa as a hegemonic power in Southern Africa ${ }^{1}$ (cf. Rotberg 1985; Pisani 1994; Van Wyk 1997; Ahwiring and McGowan 1998; Hamill 1998; Landsberg 2000; Habib and Selinyane 2006; Flemes 2009). Their use of the term, however, is usually confusing. When fleshed out in further detail, the idea of hegemony has been exposed to an astonishing degree of conceptual stretching (Collier and Mahon 1993), ranging from sub-imperial dominance (Grundy 1979; Thompson 1988; Bond 2004) to very lax leadership (Taylor 2011; Alden and Schoeman 2016). Thus, despite its resonance among political scientists, politicians and pundits, the concept of hegemony has become increasingly incoherent and lacking empirical or theoretical utility when applied to this particular region (cf. Sartori 1970; Collier and Mahon 1993; Gerring 1999; Goertz 2006).

CONTACT Luis L. Schenoni Ischenon@nd.edu 
A concise definition of hegemony is indispensable as a starting point in order to determine whether or not South Africa's relationship with its most immediate neighbours fits the ideal type. A literature review suggests that six fundamental dimensions characterise hegemony: It is a situation of (i) great material asymmetry in favour of one state - the hegemon - who has (ii) enough military power to systematically defeat any potential contester in the system, (iii) controls the access to raw materials, natural resources, capital and markets, (iv) has competitive advantages in the production of value added goods, (v) generates an accepted ideology reflecting this status quo; and (vi) is functionally differentiated from other states in the system, being expected to provide certain public goods - such as security, or commercial and financial stability. This broad definition is derived from a long tradition of IR scholarship ${ }^{2}$ (Kindleberger 1973; Krasner 1976; Gilpin 1981; Keohane 1984; Strange 1988; Lake 1993; Mearsheimer 2001), and suggests that South Africa has not been hegemonic in Southern Africa at least since the end of apartheid.

Curiously, authors who acknowledge that 'South African hegemony is neither complete in its material form, nor has it demonstrated consistent ability to exercise leadership even where it has the means available' (Alden and Schoeman 2016, 241) have been reluctant to abandon the concept of hegemony to define the structure of international relations in Southern Africa. These authors rather opted for the use of misleading sub-types, such as 'symbolic hegemony', 'cooperative hegemony' (Flemes 2009), 'benign hegemony' (Van Wyk 1997) and the like. These 'hegemonies with adjectives' would be useful if there was some empirical necessity for nuance and alternative ideal types were missing. Yet given the existence of more suitable concepts in IR, this has simply obscured the debate and prevented a comparative understanding of the Southern African power dynamics in relation to other regions of the world.

Unipolarity is a particularly appropriate concept at hand. The adjective unipolar describes a system where a single country commands a comparatively large share of capabilities that can be used to accomplish its ends and, at the same time, excels in all indicators of power - population, resource endowment, economic capacity, military might, etc. - yet does not necessarily conform to the definition of a hegemony (Wilkinson 1999; Ikenberry, Mastanduno, and Wohlforth 2009; Brooks and Wohlforth 2008). Unipoles are expected to lead by actively participating in binding regional institutions, building ad hoc 'coalitions of the willing' to deal with major security or economic challenges, struggling for legitimacy without applying a great deal of coercion, and respecting the sovereignty of second-tier states, which are considered crucial partners (Wohlforth 1999; Pape 2005; Finnemore 2009; Walt 2009). Although South Africa was indisputably hegemonic during the Cold War, the unipolar ideal type just described seems to fit the case of postapartheid Southern Africa more precisely. ${ }^{3}$

The remainder of this article is divided into three sections. The first section debates the South African hegemony in its region, distinguishing a first period of functional and stable hegemony and a second period of hegemonic decline and intense contestation. The second section analyses the changes in the regional subsystem after the fall of apartheid, and argues that unipolarity, instead of hegemony, better describes power distribution and foreign policies since the early 1990s. Finally, a third section focuses on the behaviour of second-tier regional powers - Angola, Mozambique and Zimbabwe - finding that these states also behaved according to the changes in the regional power structure. The merits of this conceptual endeavour are evaluated in the conclusion. 


\section{The rise and fall of South African hegemony}

Because of its mining riches and its strategic location, securing commerce from Asia and oil trade from the Gulf, Southern Africa was a particularly wealthy sub-continent, and one of key geopolitical importance to the great powers since the beginning of the twentieth Century. After the Anglo-Boer War, the fear that Afrikaners would succeed in creating a pro-Dutch or pro-German independent state led London to 'augment the idea of a nation-state by creating a staunchly pro-British state dedicated to protecting British interests' (Vale 1996). Therefore, the Union of South Africa gained partial independence in 1910, occupying a subservient, stabilising role in its regional periphery.

The special role that the British reserved for South Africans was evident during the Great War (when Pretoria was asked by the British Empire to seize German South West and East Africa) and also during World War II (when South Africans supported allied efforts in Malagasy, Italian East Africa and the North African theatre of operations), but the two World Wars would enhance South African preponderance even further. On the one hand, the National Party (NP) would succeed in mobilising the Afrikaner national consciousness on a mass level. This was already evident after the centenary of the Great Trek in 1938 (Söderbaum 2004, 59), but reached its apex in the post-war era, leading to greater strategic thinking and foreign policy autonomy. On the other hand, the economic crisis and scarcities of war facilitated the upsurge of a competent national bourgeoisie that, together with a capable bureaucracy, erected an autonomous South African economy. Such a drastic turn meant an 'aggressive rupture with the British state and British firms $[\ldots]$ ' while '[...] major new advancements in higher-wage, industrial production were propelled by the South African state' (Martin 2013). Due to this import-substitution industrialisation process, Pretoria became an exporter of manufactures and importer of cheap African labour for mining and farming, a regional economic structure that remains almost intact to the present day.

In subsequent years, South Africa engaged its region with manifest hegemonic intentions. In 1946, it refused to surrender its mandate over South-West Africa (Namibia) and began to administer the territory as a de facto fifth province. In 1955, Pretoria took control over the British base of Simonstown and one year later, during the Suez crisis of 1956, it overtly defied the Commonwealth position. Despite its trifling military budget, South Africa was behaving as a grown up state, ready to take care of foreign and defence policies. Moreover, it was already claiming influence over Southern African territories that would pass from the orbit of London to that of Pretoria (Vale 2003). Thus, when South Africa became an independent republic in 1961, it was already a fully-fledged regional hegemon (Saunders and Southey 1998).

\section{The zenith of South African hegemony 1961-1975}

In full control of its foreign policy, Pretoria promoted the independence of the British enclaves of Basutoland and Bechuanaland, which gained their sovereignty in 1966 as Lesotho and Botswana respectively. Two years later Swaziland also became independent, and the three of them entered the orbit of the Union by a renegotiation of the 1909 Southern African Customs Union (SACU) agreement in 1969 (Davenport and Saunders 2000). 
By 1965 South Rhodesia had also declared its independence from Great Britain. The international community never recognised it, and several guerrillas based in Tanzania and Zambia started to confront the segregationist regime of lan Smith. Claiming authority over security matters in its more proximate periphery, South Africa refused to respect the arms embargo that the Security Council imposed on Rhodesians. In 1967 Pretoria decided to send police units to the Zambesi border and conscripts to the Rhodesian army (Davenport and Saunders 2000), while continuously providing petroleum and military hardware for the Rhodesian regime, acting as a suzerain state rather than an ally (Poku 2001). In a similar vein, Pretoria enforced its claims in South-West Africa by force after its mandate was formally terminated in 1966. Southern Africa was considered Pretoria's backyard, an area of influence where its dominance was to be respected disregarding international law.

To summarise, the 1960s were the apex of Pretoria's regional hegemony, signalled by a foreign policy of asymmetric cooperation and the 'assertive incorporation' (Pisani 1994) of newly independent states to the South African economic orbit. The Portuguese from the 'Overseas Provinces' and the Rhodesians, together with South African military, police forces and intelligence services, held regular meetings to enforce hegemonic stability against subversive communist guerrillas, and Pretoria had a central role in providing intelligence, men and military equipment for these operations (Meneses and McNamara 2014). Even the state leaders that were ideologically on the side of the liberation movements, as was the case with Kenneth Kaunda's regime in Zambia, had to be very pragmatic in order to preserve their material interests (Burdette 1984). ${ }^{4}$ In the words of a notorious expert:

As the 1970s opened, there was little evidence that the regional status quo could change. South Africa remained firmly in control of Namibia and the determination of Rhodesia's white minority illegally to cling to power enhanced South Africa's position as the anchor of external interests in the region. To the east and to the west, the Portuguese appeared determined to hold on to their Southern African colonies at any cost, and this resolve further strengthened the hegemony of the apartheid state. (Vale 1996)

A total disrespect for sovereignty, which is characteristic of hegemonic settings, was also present during the zenith of South African hegemony. 'The distinction between the Homelands and neighbouring countries was rather academic' (Söderbaum 2004) since, for apartheid ideology, the main distinction was rather built on racial considerations.

Until 1974, South Africa continued to meet all necessary requirements to be a hegemon. It presented (i) great material asymmetry with regard to its neighbours, its population quadrupling that of other second-tier states in the region, ${ }^{5}$ its GDP was more that fifteen times that of any other in the region, and its national capabilities - as measured by the Composite Index of National Capabilities $(\mathrm{CINC})^{6}$ - were nine times superior to any potential challenger.

By any consideration, South Africa also had (ii) enough military power to systematically defeat any potential contester in the system in overt war. The South African Defence Force (SADF) shared this perception, which was made evident in the decision to invade Angola one year later. South African military expenditures were nine times those of Luanda by then, while its military personnel was more than two times the average of second-tier Southern African states. ${ }^{\text {? }}$

South Africa also (iii) controlled the access to raw materials, natural resources, capital and markets. Besides the overwhelming natural wealth of South African lands - gold 
production reached its historical peak in 1970 with one thousand tons exported - its manufactured goods were widely sold in the region, SACU secured market preferences in immediate peripheral states and the whole region participated in a de facto Rand monetary zone. Technological innovations and a modern business sector allowed South Africa to (iv) maintain a great margin of competitive advantages in the production of value added goods as well.

It is also arguable that, up to 1974, Pretoria had (v) generated an accepted - or at least acquiesced to - ideology reflecting this status quo, since the tenets of apartheid were faint-heartedly countered by a handful of political leaders. Rhodesians and the Portuguese overtly shared this dogma and elevated Pretoria to the role of security provider, therefore (vi) functionally differentiating South Africa, who was expected to deliver this public good for the system.

However, this situation was not meant to last. South African foreign policy started to acknowledge the changes in the regional balance of power after the Revolução dos Cravos coup on 25 April 1974. In a year or so, the abrupt end of Portuguese colonialism in Angola and Mozambique brought two secondary regional powers onto the stage that overtly opposed Afrikaner hegemony and apartheid politics. The ranks of the Frontline States were suddenly increased to an impressive extent. As if a domino effect occurred, the Movimento Popular de Libertação de Angola (MPLA) and the Frente de Libertação de Moçambique (FRELIMO), previously based in Tanzania and Zambia, now promised to support the 'struggle' in Namibia, Rhodesia and even inside South Africa. ${ }^{8}$

Acknowledging this new situation, South African Prime Minister Balthazar Johannes Vorster redesigned Pretoria's foreign policy in October 1974, proposing the search for regional partnerships. The 'deténte' doctrine promoted by Vorster envisaged a negotiation with anti-colonialist governments. Still acting as a hegemon, Pretoria unilaterally decided to pull South African Police forces out of Rhodesia and negotiated in the name of lan Smith's regime, offering assurance that he would liberate political prisoners in exchange for Zambia's compromise to prevent infiltrations from its territory. Under the pressure of the hegemon, Rhodesians accepted playing the role of a 'sacrificial lamb', but the failure of formal negotiations in August 1975 - held in a train halfway across the Victoria Falls Bridge, between Zambia and Rhodesia - led to the abrupt end of 'détente'.

In the following five years, South Africa would quadruple its military budget and its Bureau for State Security (BOSS) would be specifically entitled to build new regional alliances through a wide range of tactics that included diplomacy, intimidation and corruption. It was the end of the invincible South African hegemony of the 1960s, and the start of a diminished, coercive hegemony.

\section{The long hegemonic decline 1975-1990}

When FRELIMO was up to declare independence on 25 June 1975, the Defence Minister of South Africa, Pieter Willem Botha, considered the possibility of a military intervention (Davies 1985), but the 'détente' doctrine prevailed then and Pretoria decided to impose sanctions instead. However, after the Victoria Falls Conference failed, the SADF turned against the MPLA and launched Operation Savannah, invading Angola from the south capturing Benguela and Lobito - while another column invaded from the north, jointly with the National Union for the Total Independence of Angola (UNITA). 
In the end, the lack of support from the United States and the involvement of Cubans and the USSR doomed the campaign, and the MPLA declared independence on 11 November 1975. South Africa continued backing UNITA's leader Jonas Savimbi, thus fuelling protracted civil war (Davenport and Saunders 2000). Pretoria enacted a similar strategy in Mozambique, supporting the Resistencia Nacional Moçambicana (RENAMO), a guerrilla movement that waged a sixteen-year civil war against FRELIMO. It also fortified the entire Ovamboland - Namibia's most populated region - in order to avoid infiltration and fight SWAPO (Ross 1999), while resuming its cooperation with Rhodesia. However, the change from an offensive to a defensive doctrine was notable.

The 'détente' aftermath was characterised by a 'crude cocktail of economic, military and diplomatic measures, commonly referred to in the literature of the period as 'destabilization' (Hamill 1998). Botha succeeded Vorster as Prime Minister of South Africa in 1978, and Pretoria's regional policy evolved to a 'Total Strategy' that a contemporary summarised as follows:

[...] new instruments were also developed to achieve these reformulated regional policy objectives. Military expenditure more than doubles between 1977/8 and 1984/5 to reach almost R 3.755 million and new capabilities were developed to mount aggressive assaults against regional states. At the same time considerable attention was given to ways in which economic links could be used to further the apartheid state's regional objectives. The Botha regime's strategic planners began to consider the ways in which 'economic action' - mobilized through the network of structures controlled by the State Security Council - could be applied either in the form of 'incentive levelers' to those states showing willingness to collaborate or as 'disincentive levelers' against those seen as hostile. (Davies 1985)

Botha's initiative of a Constellation of Southern African States (CONSAS) was announced in early 1979. This aimed to shelter the region from foreign sanctions, isolate liberation movements and the countries that provided them with sanctuary, safeguard markets for South African exporters, and increase the economic dependence of other Southern African economies (Gibb 1998). Yet, overwhelmed by the Angolan defeat, the possibility of Cuban intromission and the lack of support from Western powers, Botha failed to give enough support to the Rhodesians. The ZANU grasped power, declaring independence on April 18, 1980, as the Republic of Zimbabwe. That same year, nine states - including Frontline States and those in the orbit of South Africa - created the South African Development Coordination Conference (SADCC), with the main purpose of reducing their economic dependency.

South African prospects of maintaining a hegemonic position in Southern Africa were therefore bleak by the mid-1980s, but, notwithstanding the fact that it was no longer an accepted hegemon in the region, Pretoria did not give up. It still secured three out of the six dimensions of hegemony: it had (i) great material asymmetry in its favour - its GDP had doubled in ten years; it had retained (ii) enough military power to systematically defeat any potential contester in the system - its military expenditures having also doubled - and it still possessed (iii) huge competitive advantages in the production of value added goods. Therefore, it was presumably possible for the South African elite to regain market control and restore its legitimacy as security provider by fighting back the 'communist' governments proliferating in the region (Table 1). 
Table 1. Dimensions of hegemony over time.

\begin{tabular}{lllll}
\hline & early 1970s & early 1980s & early 1990s & early 2000s \\
\hline Material asymmetry & $\checkmark$ & $\checkmark$ & $\checkmark$ & \\
Military superiority & $\checkmark$ & $\checkmark$ & & \\
Market control & $\checkmark$ & $\checkmark$ & $\checkmark$ & $\checkmark$ \\
Productivity gap & $\checkmark$ & & & \\
Ideological consensus & $\checkmark$ & & & \\
Exclusive functions & $\checkmark$ & &
\end{tabular}

Source: Elaborated by the author.

This period can be labelled one of hegemonic crisis or coercive hegemony (Lake 1993). ${ }^{9}$ The use of a diminished concept of hegemony in order to describe the regional context during the years 1975-1989 is justified by the fact that the subsystem was not unipolar yet, particularly in behavioural terms. Pretoria continued to claim hegemonic status and acted in consequence. But the intents to restore South African hegemony had a powerful economic impact. One author says that:

As sanctions advanced internationally and national liberation movements came to power in 1975 and 1980, the regional spaces open to South African and foreign firms contracted. By any measure-trade, investment, or migration-relationships between South Africa and all her neighbours plummeted. (Martin 2013)

The economic hegemony of South Africa remained strong in the $1980 \mathrm{~s}$ as it still produced three times the total national product of all SADCC countries by the end of the decade (Döpcke 1998). In the military realm, Pretoria also behaved as if unmatched. Yet the strategic environment would become increasingly fragile. Except for countries like Swaziland and Malawi - which still behaved as conservative allies - countries such as Angola, Lesotho and Mozambique were frequently targeted by increasingly costly interventions. In 1981 the SADF attacked units of the ANC in Matola, Mozambique, and the frontiers between the two countries were practically closed, causing great damage to regional economies. ${ }^{10}$ In 1986, air strikes against ANC bases in Harare, Luanda and Garbone also took an indirect toll on Pretoria's economy. However, it was only after the victory of the MPLA forces in the 1988 battle of Cuito Cuanavale that South Africa became conscious of the fact that it could not 'systematically defeat any potential contester in the system' and therefore that coercive hegemony was not sustainable anymore (Mills and Williams 2006; Cfr. Krasner 1976).

Finally, the anti-communist credentials that were key to the apartheid regime's survival became obsolete with the end of the Cold War. The diplomacy of isolation (Geldenhuys 1984) was brought to an end. South Africa finally recognised its fate and renounced hegemony together with apartheid. The costs of coercive hegemony for Southern Africa totalised in - following the most conservative estimates -1.5 million deaths, more than 10 million displaced people, and over US\$ 60 billion of potential economic growth (Vale 1996).

\section{The end of apartheid and the unipolar subsystem}

In February 1990, President de Klerk declared that the 'season of violence' was over in Southern Africa, opening the path to a unipolar regional order where South Africa would no longer be pariah, but leader.

Pretoria's New Diplomacy overtly deposed the use of military means, ended the Angolan Bush War, and withdrew from Namibia, where free and fair elections were held 
in November 1989 and independence was declared a few months later. In Angola and Mozambique, South Africa started to act as pacifier instead of an agent of discord. MPLA and UNITA tried - unsuccessfully - to end civil war through the Bicesse Accords (1991) and the Lusaka Protocol (1994). FRELIMO and RENAMO achieved a partial ceasefire in 1990 and a comprehensive peace accord two years later, which secured peace and transition to democratic rule. Moreover, Pretoria made the big step of joining the Nuclear Non-Proliferation Regime in 1991, having all nuclear weapons destroyed two years later.

The year 1994 signals the end of apartheid in South Africa with the oath taken by Nelson Mandela as President of South Africa. His famous '[l]et freedom reign. God bless Africa' (Ross 1999), opened a whole new chapter in Southern African regional politics. The notion of 'African Renaissance' filled post-apartheid diplomatic discourse, signalling the beginning of a new era of increasing trust and confidence among neighbouring countries, built on the bonds that the ANC had with governments that gave sanctuary to their members during 'the struggle'. Last, but not least, Mandela explicitly renounced the quest for a South African hegemony in the region (Hamill 1998).

Because of the loss of its military pre-eminence, South Africa was not hegemonic, nor could it claim hegemony in its more proximate periphery. South African military expenditures were only double those of Angola by 1993, while the armed forces numbered half the personnel of the Angolan military (Singer, Bremer, and Stuckey 1972).

It is true that South Africa's productive primacy was intact, being the only country in the region with a modern manufacturing sector. Huge economic asymmetries were also evident in the financial and infrastructure sectors. Moreover, after the pariah regime fell down, with branch offices heralding South African FDI, consumer goods and construction projects proliferated in the region (Daniels, Southall, and Naidu 2008). There's no question that, by 1995 , South Africa represented $87 \%$ of all sub-Saharan production of manufactures, had a greater than five-to-one trade imbalance in its favour with other Southern African countries, and its GDP was three times that of all these countries put together (Kibble, Goodison, and Balefi 1995). These facts led some to characterise the early 1990s as a 'hegemonic moment' (Alden and Schoeman 2016), but the lack of military might indicated a unipolar moment (Krauthammer 1990); a situation of unipolarity without hegemony (Wilkinson 1999). Foreign policy is decided upon with one eye on economic power, and the other on military might - the rule of thumb was as important then as it is important now to understanding the implications of a rising Angola with prodigious military expenditures.

During the following two decades, South African material primacy would be further put into question, as shown in Figure 1. As one can see, the current situation is better understood as a uni-bipolarity (cf. Huntington 1999; Schenoni and Actis 2014), given that Luanda has achieved virtual parity in the military realm while remaining far from Pretoria's record in the economic realm.

\section{Behaving like a unipole: legitimacy, institutions and regional stability}

The key to determining the existence of a unipolar context in the 1990s is not only material but also behavioural. South Africa reluctantly started to behave like a unipole, trying to lead by actively participating in binding regional institutions, building ad hoc regional 


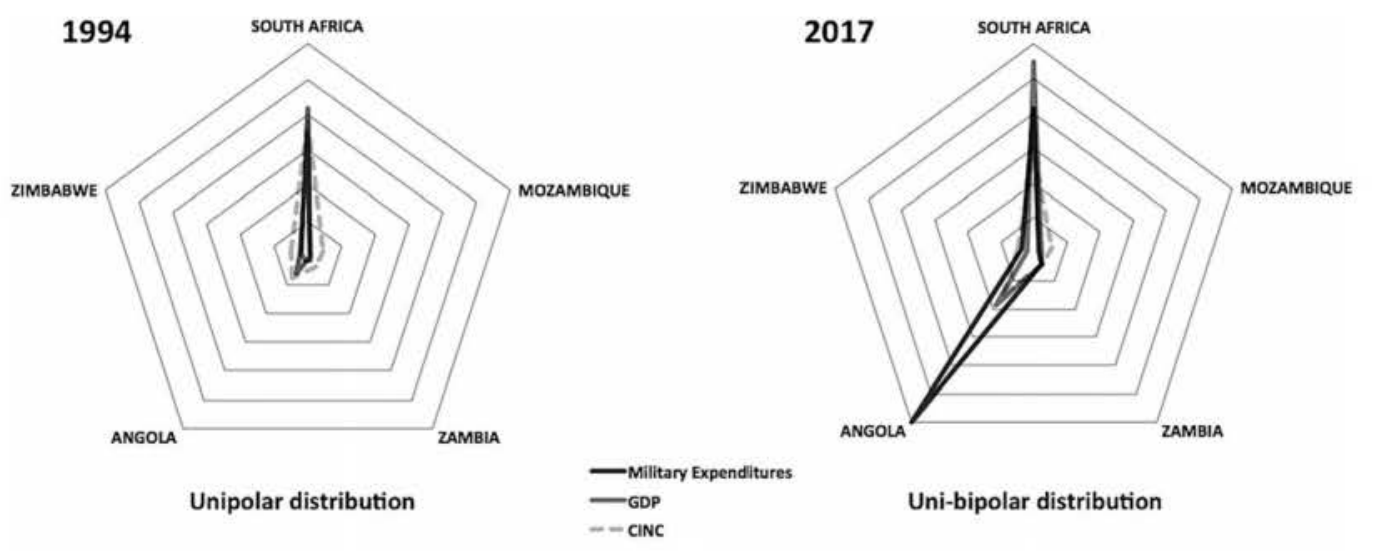

Figure 1. South African material primacy vis-à-vis second-tier powers. Notes: Each concentric pentagon roughly represents: $0.2 \%$ of global national capabilities (light-grey dotted line), 60 billion USD of GDP (grey line) and 2 billion USD of military expenditures (black line). Figures for 2017 are estimated by projecting the general trend of the last ten years.

Sources: World Bank, SIPRI and Singer, Bremer, and Stuckey (1972).

coalitions to deal with major security or economic challenges, struggling for legitimacy, avoiding coercion and thoroughly respecting the sovereignty of second-tier states, which were considered crucial partners instead of potential challengers ( $\mathrm{Cfr}$. Finnemore 2009; Walt 2009).

In terms of legitimacy, South Africa, despite the great expectations generated by the end of apartheid, was 'far from being seen as a benevolent hegemon [...][and was rather seen as a] selfish hegemon bent on advancing its narrow economic interests at the expense of less developed African countries' (Flemes 2009). Consensus-building strategies enacted by South Africa in its region were therefore extremely cautious. To avoid being isolated, Pretoria circumvented direct claims to leadership in order not to awake any memories of apartheid's regional policy (Schoeman 2003; Flemes 2009). Yet, great political and economic investment in legitimating Pretoria's leadership role were transferred to Mandela's 'African Renaissance', Mbeki's 'Africa first' policy and Zuma's 'African Agenda'. It was in this quest for leadership that South Africa reorganised its development cooperation under the Ministry of Foreign Affairs to challenge established donors in the region (Landsberg 2014).

Even greater was the political concession of participating in a regional set of institutions whose design could not be influenced by Pretoria. After recognising the poor merits and achievements of the organisation, SADCC member states dissolved the organisation and signed the Southern African Development Community (SADC) in 1992. South Africa joined as the eleventh member of SADC in 1994. Nevertheless, the logic of SADC was far from functional for South African interests. Still mistrusting the NP, SADC members decided to 'prepare unified negotiating positions on trade and other economic issues, craft a treaty based on progressive principles and entrench the concept of 'balance, equity and mutual benefit' as the maxim for regional co-ordination' (Nathan 2012). In other words, South Africa chose to bind itself (Ikenberry, Mastanduno, and Wohlforth 2009) as a strategy in order to gain legitimacy in the region. Not surprisingly, some authors noticed that 'efforts to reposition SADC in the aftermath of the ending of apartheid have been primarily 
hampered by South Africa's nervousness to be drawn too closely into a regional scheme over which the country has no immediate control' (Vale 1996).

Even if institutions often imply more costs than benefits for South Africa, 'Pretoria's foreign policy is an example of exercising power by participating effectively in regional and international institutions' (Flemes 2009). This is so precisely because the bilateral approach - more characteristic of hegemonic settings - was not possible anymore. Even the SADC free trade protocol in $\mathbf{2 0 0 0}$ - which was arguably a South African initiative considered 'balancing measures, such as budgetary transfers, a regional development fund and postponed trade liberalization prioritizing the weakest members' (Söderbaum 2004). The capacity of second-tier powers to trump these South African plans to regain market control was manifest in 2010, when the compromises to conform a Common Market (2015), a Monetary Union (2016) and establish a single currency (2018) were all suspended by other SADC members.

Moreover, these institutions have been used by states other than South Africa - primarily Angola, Mozambique and Zimbabwe - for the purpose reinforcing their sovereignty. As one author points out:

The SADC is used as an image-boosting arena whereby the leaders show support for each other, regardless of the character of their regimes. The SADC meetings are gigantic and even majestetic events where the political leaders can show to the world and their citizenries both that they are promoting the cause of regionalism and that their political regime is important on the international scene. Decision-making within SADC is highly formalized, and to some extent even ritualized. SADC summits are, to a significant extent, image-boosting exercises where the regimes can express their loyalty to each other, praise their authoritarian regimes and the values and goals of their regional organization. (Söderbaum 2004)

But as academic and political discourse continues to show, South African authorities were sometimes reluctant to abandon the hegemonic ideal, which produced certain problems. In this sense, the most notable offshoot of Pretoria's quest for legitimacy was disenchantment. Expectations that South Africa would become a benevolent leader were followed by bitterness when ANC leaders adopted a far more realist position and used its new image and prestige as a foreign policy tool to pursue egoistic interest. The persistence of a conservative defence doctrine, the connivance with the arms industry, and the stubborn promotion of South African economic interest abroad remained untouched (Hamill 1998). The idealism of the 'Reconstruction and Development Program' that the ANC presented as its road map to engage Southern Africa was replaced in 1996 by a more pragmatic 'Growth, Employment and Redistribution' strategy, downgrading the prospects that Pretoria would act as a benefactor, and showcasing the crude neoliberal interests of their elites. While South Africa presented itself as a champion of African development in the region and abroad, at the same time it promoted market oriented economic policies - through New Economic Partnership for African Development (NEPAD), African Peer Review Mechanism and SADC's free trade protocol - and hypocritically subsidised the expansion of its own FDI (Flemes 2009). This quest to regain some market control in the region - an element of hegemony lost since the formation of SADCC - was a fiasco that severely damaged the prestige of ANC leaders.

It has also been stated that South Africa's position with regard to diplomatic or military interventions in its own region was as schizophrenic as its economic discourse (Habib and Selinyane 2006), moving between principled and pragmatic approaches. However, the 
dilemmas of unipolarity may explain these apparent contradictions. In unipolar settings, leading regional powers are expected to intervene - under the legitimacy of regional institutions - in small states, while respecting the sovereignty of second-tier regional powers that can resist intervention and succeed in delegitimizing the unipole. This is exactly what South Africa did. Pretoria actively intervened in countries such as Lesotho (1994 and 1998), Swaziland (1994 and 2012) and Madagascar (2009), but avoided any kind of intervention in Angola - at war until 2002 -, Zimbabwe - which presented numerous episodes of violence since the year 2000 - and the brief return of civil war in Mozambique (2013). ${ }^{11}$

The landlocked enclave of Lesotho provides us with a paradigmatic case. After a constitutional crisis in 1994, which was mediated by Mandela, Mugabe and the President of Botswana, Quett Masire, this small state aligned its foreign policy with Pretoria's. Smooth bilateral relations were only interrupted during the 1998 looting of Maseru, an episode of political instability that threatened South African assets and water supplies, and led to the government of Lesotho requiring foreign support. For some authors, the military intervention that stabilised the country looked similar to other hegemonic-like apartheid interventions (Mahao 2006), but this time Pretoria cared to intervene through a 'coalition of the willing' - joined by Botswana - and with a SADC mandate. ${ }^{12}$ Unlike a hegemon - and much like a regional unipole - South Africa's military intervention in this small state was preceded by a quest for legitimate leadership and burden-sharing with other actors in the system.

The domestic crisis in Swaziland in 1996 was also tackled by the combined action of SADC leaders (Vale 1996) and in 2012, when the country suffered serious economic constraints because of the reduction in SACU receipts, South Africa tried to foster some political reforms as a precondition for releasing a loan. Similarly, during the 2009 Madagascar crisis, Pretoria was ready to suspend the country's membership in SADC and even threatened them with military intervention.

The standard applied to these small states was astonishingly different to that applied to second-tier regional powers, whose sovereignty was respected meticulously. South Africa has not only avoided any intervention in the internal affairs of Angola, Mozambique and Zimbabwe, but also allowed these countries to behave as stabilisers in their own periphery. This seems to be the case with the Angolan intervention during the Caprivi conflict in Namibia (1999), Zimbabwean mercenaries deployed in Malawi during the 2011 protests, and the preeminent role of the Mozambican ex-president, Joaquim Chissano, as a mediator during the 2009 Madagascar crisis.

As is the case for unipolarity in the global realm and other unipolar regions such as South America, this particular setting has resulted a relatively peaceful and stable one for inter-state relations. Only two militarised interstate disputes between Angola and Zambia (1998) and Zimbabwe and Botswana (2008) achieved relevant levels of tension. It was only in the Lesotho crisis (1998) that South Africa deployed troops in another country.

\section{The South American mirror}

All the aforementioned aspects of South African foreign policy are also stunningly similar to what happened in another unipolar region: South America. The unipolar Brazil ' ... like South Africa, thought to create regional alliances and a regional market, with mixed 
success, again like South Africa' (Martin 2013). The way Pretoria intervened more directly in small states but refrained from doing so in the case of second-tier states shows impressive resemblances with the Brazilian-led interventions in Ecuador (2005 and 2010), Bolivia (2008), Honduras (2009) and Paraguay (2012), and Brasilia's overwhelming silence during the current Venezuelan crisis. Behavioural similarities between both regional unipoles are also evident in the way that Brazil seeks the legitimacy of the Union of South American Nations (UNASUR) - the equivalent of SADC in its region - for any intervention or mediation effort.

Figure 2 shows the resemblances between Southern Africa and South America in material, rather than behavioural, terms. While South Africa has witnessed a transition from hegemony to unipolar primacy, Brazil has been upgraded from a bipolar Argentine-Brazilian structure to the status of unipole in the mid-1980s (Schenoni 2016). The dashed line shows a system change - from bipolar to unipolar, or from hegemonic to unipolar, and so on. The threshold commonly used to differentiate bipolar from unipolar settings using the CINC (Schweller 2004; Martín 2006; Schenoni 2015, 2017) ${ }^{13}$ suggests that the Angolan rise had turned the Southern African subordinate system into a bipolar by by the early 2000 s - as suggested by the light-grey dashed line on the right. This change is still not manifest in the foreign policy behaviour of Angola, but may become increasingly so. Figure 3 shows an even clearer trend towards bipolarity in Southern Africa.

As reviewed in the first section, unipoles have to excel in all indicators of power, including military might (Ikenberry, Mastanduno, and Wohlforth 2009), and the fact that Angola has been spending more on its military than South Africa since 2013 radically questions the persistence of the historical hierarchy. As mentioned before, the current situation
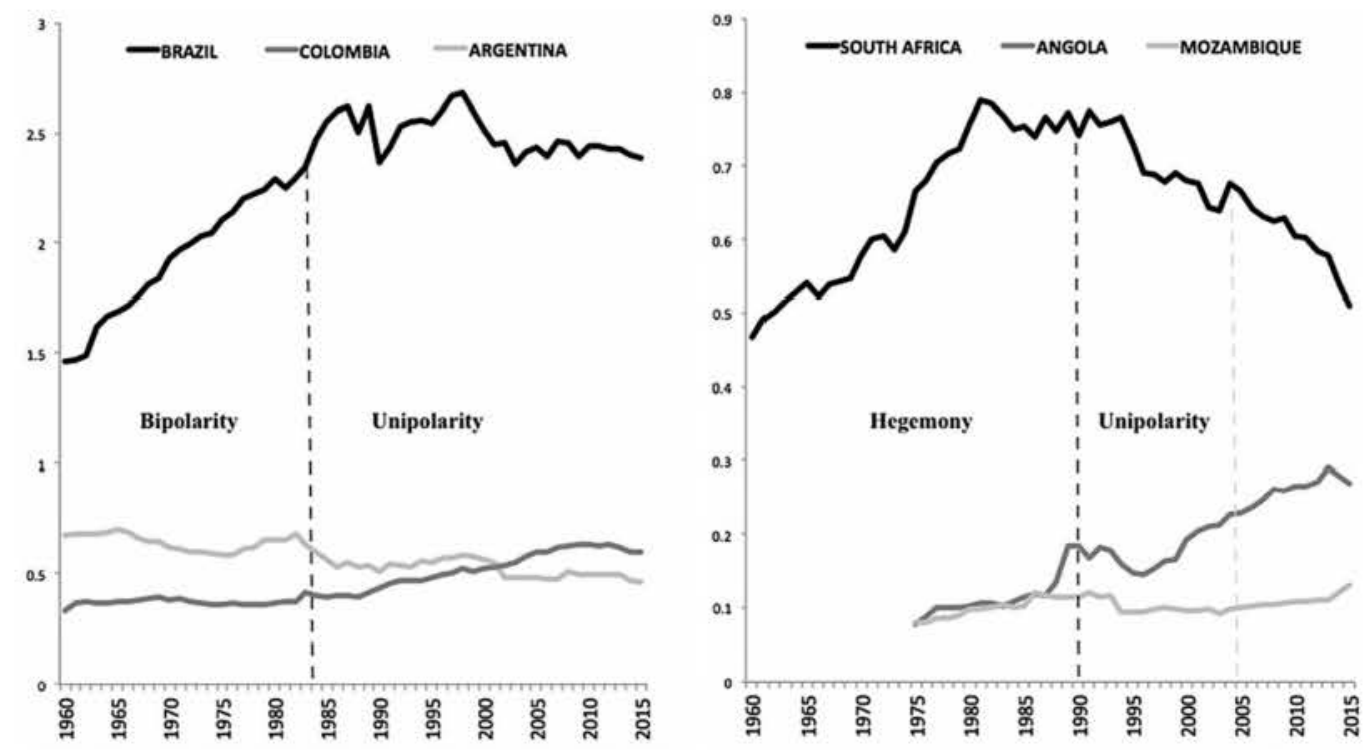

Figure 2. National Capabilities of Southern African and South American three major countries from 1960 to 2015. Notes: Values in $y$ represent the percentage of the world's national capabilities that correspond to that country. The dotted lines represent transitions to and from unipolarity. I updated the data for the period 2008-2015 using a simplified method that roughly approximates values of the composite index.

Source: CINC (Singer, Bremer, and Stuckey 1972). 

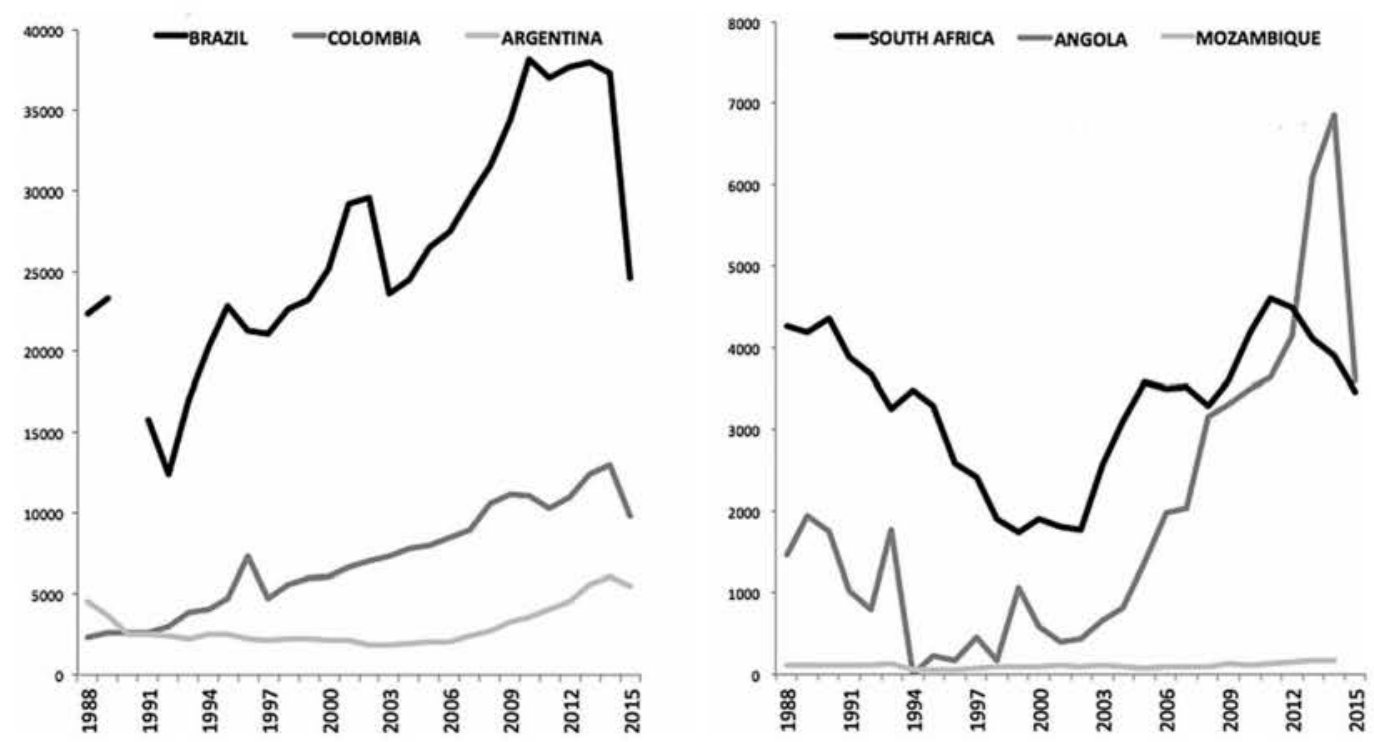

Figure 3. Military expenditures in Southern African and South American three major countries from 1988 to 2015. Notes: Figures are in US\$ millions at constant 2011 prices and exchange rates. Source: SIPRI.

could be better understood as a uni-bipolarity (cf. Huntington 1999), given that Angola attained parity in the military dimension of power while it remains far behind South Africa in the economic dimension.

In conclusion, South Africa is still is a primus inter pares in the region, both in economic and diplomatic terms. But a long time has passed since the regional system was hegemonic. In the words of Timothy Shaw: 'Hosting the Africa Cup of Nations, or FIFA World Cup, or running the continent's largest airline do not lead to regional hegemony. South Africa's soft power is separate from its inter-state status ...' (Shaw 2015). In terms of strict raw power considerations, Southern Africa has long been unipolar, and is apparently becoming bipolar.

\section{Second-tier states hedging South African primacy}

Under regional unipolarity, second-tier regional powers such as Angola, Mozambique and Zimbabwe are expected to soft-balance or at least withhold cooperation and contest South Africa's leadership (Huntington 1999; Wohlforth 1999; Ikenberry, Mastanduno, and Wohlforth 2009). Unlike small states, they are big enough to seek autonomy and defend their interests if they contradict Pretoria's. So, in the absence of domestic instability or important elite divisions, these countries should contest its leadership at the inter-state level, despite their huge interdependence with South Africa.

This strategy has been characteristic of other unipolar regions such as South America (Schenoni 2015), though in Southern Africa it can be more subtly enacted, for these states 'need to undertake little soft-balancing let alone binding as South Africa is decreasingly dominant' (Shaw 2015). In any case, there is clear evidence that second-tier states pursued a hedging strategy since the 1990s, at least when domestic stability allowed. With the rise of China, many Southern African countries were further strengthened vis- 
à-vis Pretoria since the mid-2000s, (Mouron, Urdinez, and Schenoni 2016), demonstrating that the behavioural logic of regional unipolarity passes the empirical the test in the region.

\section{Zimbabwe: from contestation to regime-shielding}

President Mugabe was not comfortable with the incorporation of South Africa as a leader in the region, particularly when it came to more political issues. When Pretoria proposed the creation of a security forum inside SADC with a rotating chair, Harare recommended instead keeping the Frontline States tradition, with Mugabe himself being the permanent chair of the forum (Cilliers 1995). From 1992 to 1995, Mugabe served as a mediator in the dispute regarding the Kaiskili/Sedudu Islands that antagonised Botswana and Namibia, clearly interceding in South Africa's more proximate backyard. In the years to follow, Zimbabwe would be the most active opponent of Pretoria with regard to the institutionalisation of regional security in Southern Africa (Nathan 2012).

The regional crisis that most clearly unveiled the differences between Zimbabwe and South Africa took place in the Democratic Republic of Congo (DRC). A trusted ally of the elected president Laurent Kabila, Zimbabwe was the first to offer support for his regime when a rebellion threatened his government in July 1998. Taking the initiative, president Mugabe set up two meetings in Victoria Falls and Harare, after which a regional intervention was announced by Angola, Namibia and Zimbabwe under the auspices of SADC, even though South Africa had not participated in either of the summits. Questioning the legitimacy of the intervention, Mandela organised a counter-meeting to promote a diplomatic resolution of the crisis, but Angola and Zimbabwe boycotted it (Berman and Sams 2000).

A week later, South Africa and Botswana decided to launch the aforementioned military intervention to prevent a coup d'etat in Lesotho. Some authors highlight that '... the Lesotho government was reported to have engaged in behind-the-scenes efforts to get Zimbabwe to intervene in Lesotho in return for supporting Mugabe in the battle against South Africa for regional political dominance' (See Makoa 1999; Nathan 2012), which may explain the calamitous celerity of Pretoria's intervention. During the Lesotho crisis, Harare understandably criticised the way Pretoria disregarded the absence of a clear SADC mandate, but the dispute ended in a quid pro quo, with Mandela accepting and supporting the military intervention in the DRC, and vice-versa. Only one year later would South Africa lead a diplomatic initiative that facilitated the Lusaka accord, and it took until 2002 for president Mbeki to secure the progressive withdrawal of foreign troops from the DRC.

Zimbabwean contestational tactics were downgraded since the year 2000 because of the domestic crisis that followed that year's constitutional referendum, confronting the Zimbabwe African National Union-Patriotic Front (ZANU-PF) with the Movement for Democratic Change (MDC) in the decade to come. State repression and violence increased steadily. Zimbabwe was harshly represented by human rights organisations, severely sanctioned by western democracies and financial institutions, and reached the second position in the list of failed states with an inflation of $13,000 \%$ by the end of the decade, and with a quarter of its population displaced. The Mugabe Regime fell into increasingly dire economic straits. In the ten years from 1998 to 2008 , Zimbabwe suffered a cumulative consecutive fall of around $38 \%$ of its GDP. 
During this crisis South Africa acted as a unipolar regional power would in relation to a second-tier potential contester. First, it contributed to securing Zimbabwean sovereignty and Southern African regional autonomy, sheltering the authoritarian regime from extra regional criticism. Pretoria openly opposed sanctions applied by the EU, the United States and Commonwealth states, presenting them as an intromission in African affairs and displaying a huge diplomatic effort in order to prevent the Zimbabwean suspension from Commonwealth and secure its invitation to the Abuja Summit of 2003 (Masunungure and Badza 2010).

Then, when repression in Harare increased after March 2007, the stabilisation of the country and the exhibition of SADC as a successful regional forum became a priority for president Mbeki. He himself was proposed as a mediator in an extraordinary summit of SADC in Dar-es-Salaam. Afterwards, several analysts would agree that he distorted the truth in official reports, dishonoured his role as a mediator, and authorised the selling of light weapons to Zimbabwe in order to achieve stabilisation. No other president in Southern Africa went so far in backing Mugabe. It was surprising that South Africa - a celebrated democracy itself - applied such 'quiet diplomacy' to a previous contester for its regional leadership, but the logic of unipolarity explains this apparent paradox quite well. South Africa was not strong enough to discipline Mugabe, and its image as a leader was so tarnished by the Zimbabwean breakdown that stabilisation at all costs became a viable policy. In the words of two Zimbabwean scholars:

Thabo Mbeki's role in the resolution of the Zimbabwe crisis was against the backdrop of the duel between then President Nelson Mandela and Mugabe over control of the SADC Organ on Politics, Defence and Security Co-operation (OPDSC) and the role and institutional relationship between the OPDSC and the SADC. An SADC 'cold war' had ensued, souring relations between South Africa and Zimbabwe. Therefore, when Thabo Mbeki took over from Mandela in 1999, he consciously sought to mend and strengthen the bilateral relations between South Africa and Zimbabwe [...] he was pursuing strategic economic interests in the form of investment opportunities for the ever-expanding South African economy. [...] He also intended to continue raising South Africa's stature as the ideal caretaker on the continent. (Masunungure and Badza 2010)

These circumstances did not change with the change of the South African leadership: 'While it was suggested at some point that Zuma would adopt a much tougher stance vis-à-vis Mugabe, in the end he continued to work with all three parties of the GNU [the Mugabe-led Zimbabwean Government of National Unity]' (Landsberg 2014).

Pretoria was increasingly held responsible by the international community for the enforcement of human rights in the region. It became a central foreign policy dilemma 'how to admonish the Zimbabwean regime without appearing to side with the West against an African brother nation again' (Flemes 2009), but South Africa always sided with Mugabe, as a unipole would do. Harare, in turn, acted as a typical second-tier regional power under unipolarity, making use of regional organisations like the African Union (AU) and the SADC that, together with Pretoria, were available to endorse fraudulent elections and violations of human rights (Nathan 2012).

\section{Mozambique: still interdependent and yet autonomous}

Mozambican bilateral relations with South Africa have changed very little since the end of the Comprehensive Peace Agreement of 1992, which brought peace to the country after sixteen 
years of civil strife. In relative terms, Maputo was an active proponent of economic integration and regional cooperation with the regional unipole. In turn, South Africa was the first great investor in Mozambique after the civil war, and remains the first market for its exports.

Why did Maputo, while being economically and militarily comparable to Harare, not contest South African leadership in the same way? When one poses this question to high Mozambican officials, the answer is either that they 'were more concentrated in domestic political problems' or that the Zimbabwean bureaucracy 'had far better trained cadres'. ${ }^{14}$ Be it a cause of domestic political unrest (Schweller 2004), or a lack of state capacity (Zakaria 1998; Taliaferro 2006), realist IR theory has already theorised that these factors could prevent balancing behaviour. However, the main reason seems to be interdependence. Historically, southern Mozambique has been economically and culturally closely interrelated with the Transvaal region, a relationship that has been governed since 1995 by the Maputo Development Corridor - the most paradigmatic case of 'micro-regionalism' in Southern Africa (Söderbaum 2004). In sum, Mozambique is far more integrated into South Africa than any other second-tier state in this region.

Constrained by these factors, the foreign policy of President Joaquim Chissano (19862005) was nevertheless largely determined by the intention to diversify Maputo's partners, particularly among western democracies. His successor, Armando Guebuza (2005-2015), changed to a more economically driven foreign policy, characterised by a more direct focus on China, and other emerging economies, from which Mozambique received various investments. All of these efforts were intended to reduce dependency on traditional foreign donors, such as Scandinavian countries, and South Africa. The strategy has been successful to some extent. Even if Mozambique's trade deficits with South Africa have been growing in total US dollars, its trade balance is equilibrating in relative terms. While Maputo exported only $5 \%$ of what was imported in 2001 , it was already exporting a $44 \%$ by 2013 , turning the relationship into a more interdependent one. ${ }^{15}$

Moreover, Mozambican leaders, while trying not to confront Pretoria, have invested in prestige as an asset to influence regional politics. During Chissano's Presidency, Mozambique was the only second-tier regional power that neither sided with Zimbabwe nor with South Africa during the DRC crisis, which upgraded Maputo's legitimacy within SADC and allowed the country to play a key role as a political pivot both during the dispute and afterwards. In subsequent years, Chissano was appointed Chairperson of the African Union (2003-2004), Special Envoy of the Secretary General, Kofi Annan, to Uganda (2006), and acted as a crucial mediator in the 2009 Madagascar crisis.

The sheer size of Mozambique and the effectiveness of its foreign policy based on prestige became clear in the extremely circumspect reaction of Pretoria to the return of civil war. RENAMO's leader, Afonso Dhklakama, who had been denouncing fraud continuously since the 1999 elections, announced the end of the Peace Agreement and started a series of attacks in April 2013. The Summit of SADC Heads of State and Government gathered in Malawi in the midst of these crises and, instead of analysing the situation, it commended the work of Guebuza as SADC Chairperson and that of Chissano as mediator in Madagascar (SADC 2013).

\section{Angola: an emerging pole in Southern Africa}

Angolan politics followed a path that ran in the opposite direction to the Zimbabwean one, from civil war and violence to increasing stability. Consequently, during the 1990s, 
Luanda was less able to enhance its sovereignty vis-à-vis Pretoria. In 1996 an agreement was signed - mimicking a 1993 agreement with Mozambique - that allowed for a great margin of manoeuvring for South African security forces in border areas (Vale 1996, 379). Mandela acted as an important mediator, first with Mugabe, boosting support to the Lusaka Protocol (1994), and then meeting UNITA's leader, Jonas Savimbi, in May 1995.

However, the legitimacy for any mediation by Pretoria was put into question from then on, as Angola started to support Zimbabwe when security issues were raised the regional level (Nathan 2012). With time, Luanda started to feel confident enough to challenge Pretoria and make public displays of its sovereignty. In 1997 MPLA troops intruded in Congo, and in 1998 joined Zimbabwean and Namibian forces in intervening in the DRC. In 1999, Luanda launched a series of covert activities in Zambia as retaliation for the smuggling of arms to UNITA rebels. Angolan forces were also the last to leave the DRC, overlooking an agreement that disposed withdrawal by September 2002, and plainly defied the peace process led by South Africa and the UN.

The death of Savimbi in 2002, and the subsequent end of civil war, consolidated this trend. Angola has experienced unprecedented growth since then, driven by the boom in commodity prices (Seabra and Gorjao 2011] (1988)). GDP growth rates averaged 10\% during the 2000-2014 period. In 2008 alone, the country grew by an impressive $23.2 \%$. By 2010, The Economist published an article entitled 'Rising Angola', praising this miraculous ascension, which also had an impact on military expenditures and other indicators of international power - see Figures 2 and 3.

Southern African IR scholars have pictured Angola contemptuously when compared with its actual economic size and autonomy. In 2014, South Africa was still the most important exporter to Zimbabwe (42.8\% of its total imports), Zambia (32.3\%) and Mozambique $(30 \%)$, but not for Angola, being in third position after Portugal and the United States, and accounting for only a $9.7 \%$ of its imports. Moreover, Angola is the only country in the region that succeeded in reverting its trade balance vis-à-vis South Africa, which is positive since 2007. These surpluses amounted to a mean of one billion dollars during the last five years.

China has played a great role in this change. Two thirds of the petroleum Beijing imports from Africa comes from Angola, which is also the greatest borrower from the state-owned Chinese Export-Import Bank, and one of the greatest receivers of Chinese foreign investment. This may also be the reason why South Africa has been criticising Chinese economic engagement with Southern Africa (Grassi 2013; Mouron, Urdinez, and Schenoni 2016).

The political influence of Angola in the region has grown as impressively as economic indicators. In 2007 an official report from Pretoria was leaked, claiming that President Dos Santos had financed the campaign that permitted the rise of Jacob Zuma inside the ANC. Already President, in August 2009, Zuma made his first state visit to Angola, accompanied by eleven cabinet ministers and the largest business delegation a South African head of state had escorted within fifteen years (Landsberg 2014). This visit signalled the end of the frosty bilateral relations that characterised the Mbeki administration (1999-2008), and the will to engage in a symmetric partnership with Angola.

In light of all this evidence, it is surprising that Angola has seldom been considered a potential first-tier regional power. A theory of regional polarity would recommend not only the final demise of the 'hegemonic' discourse, but also the serious analysis of the 
implications of a Southern African bipolarity. The cessation of Pretoria's leadership role, the weakening of SADC, the increase in military expenditures, the resurgence of territorial disputes, and a whole set of similarly conflictive phenomena may already be characteristic of a change in regional polarity.

\section{Conclusions}

Despite the widespread use of the term 'hegemony' to refer to the role of South Africa in its more proximate regional context, this article has argued that such a term overstates the position of relative power in which Pretoria is actually situated. As one author has noticed, '[there's] no denying South Africa's overwhelming economic power, how this relates both politically and economically to the region [...] is very unclear and very much the subject of debate' (Martin 2013). Yet, this debate has hitherto been obviated by IR scholars who continue to refer as South Africa as a regional hegemon, leading to a chronic problem of concept stretching and very confusing portrayals of Southern African regional politics.

The concept of unipolarity provides a much more nuanced description of regional politics since the end of apartheid. First, it better describes the distribution of material capabilities in a region where Pretoria's economic primacy stands, but where its military might is being disputed. Second, it better accounts for the South African strategy of leading regional 'coalitions of the willing', restraining itself from unilateral action, binding itself through regional organisations and respecting the sovereignty of second-tier states. Third, it provides a better explanation for hedging strategies that secondary powers such as Angola, Mozambique and Zimbabwe have enacted when domestic and international conditions allowed. Fourth, it highlights the importance of polarity considerations at the regional level, and how these might affect state behaviour.

With the rise of Angola, Southern Africa might be turning into a bipolar subsystem, while IR scholars fail to acknowledge such huge transformation. Recently, the material underpinnings of the South African position in its immediate region have been obscured by an exclusive focus on its global status. As with Brazil in South America, this has condemned the analyses of Pretoria's foreign policy to great variance and inconsistency. Optimists were allured by South Africa's two terms in the UNSC (2007-2008 and 2011-2012), and its inclusion as the only African member in the G20 and the BRICS. Pessimists were then encouraged by the impact of domestic political turbulences and economic crises on foreign policy. Yet these perspectives divert the attention from important structural variables that underpin the long-term direction of South Africa's foreign policy towards its neighbourhood. This article has called the attention to that blind spot.

\section{Notes}

1. Since it is the purpose of this article to show that South Africa is no longer hegemonic in its more proximate periphery, Southern Africa is defined here as comprising of Angola, Botswana, Lesotho, Madagascar, Malawi, Mozambique, Namibia, South Africa, Swaziland, Zambia and Zimbabwe - i.e. the narrower definition of the region.

2. This definition excludes some interesting theoretical endeavors that have proposed different understandings in a more neo-Gramscian tradition (see Burges 2008; cf. Cox 1983).

3. In the past some scholars have voiced some scepticism regarding the possibility of applying the structural framework to the regional level. This concern is often related to Kenneth Waltz's 
assertion that ' $[\mathrm{a}]$ general theory of international politics is necessarily based on the great powers.' But Waltz also meant that, '[t]he theory, once written, also applies to lesser states that interact insofar as their interaction is insulated from the intervention of the great powers of a system' (see Waltz 1979, 73). The latter has animated some scholarship that applies the polarity debate to regions (Lemke 2002; Schenoni 2017). Here I build upon such literature.

4. It was not until the early 1970 s that the Chinese-sponsored TANZAM railway connecting the Copper Belt to Dar-es-Salaam allowed Lusaka a greater margin to maneuver.

5. South Africa's population was 24 million people in 1974 , being the most populated country in the region, followed by Mozambique (10.3 million), Rhodesia ( 6.8 million), Angola ( 6.4 million) and Zambia (4.8 million). Nowadays, only the population of Angola and Mozambique put together is roughly equivalent to that of South Africa (Singer, Bremer, and Stuckey 1972).

6. The CINC is based on six indicators of international power, which are considered relevant for a neorealist definition of the concept: energy consumption, iron and steel production, military expenditure, military personnel, total population and urban population (Singer, Bremer, and Stuckey 1972).

7. In 1975 South Africa expended 1.24 current billion dollars, against 0.14 of Angola, 0.06 of Zambia, 0.01 of Mozambique and 0.11 of Rhodesia. Military personnel amounted to 50 thousand in South Africa, 30 in Angola, 20 in Mozambique, 16 in Zambia and 15 in Rhodesia (Singer, Bremer, and Stuckey 1972).

8. '[...] Angola and Mozambique provided an invaluable collaboration to liberation movements in Rhodesia, South Africa, and Namibia, which were allowed to benefit from their military experience. It was the hospitality of the frontline countries - Angola, Mozambique, Botswana, Tanzania and Zambia - that allowed the Zimbabwe African National Union (ZANU), the Zimbabwe African People's Union (ZAPU), the South West African People's Organization (SWAPO) the African National Congress (ANC) and the Pan Africanist Congress (PAC) to intensify their military activities' (Chanaiwa 2010, 321).

9. To understand this concept of hegemonic crisis, a parallel could be drawn with the situation of the United States in Central America and the Caribbean during the cold war, where the last two dimensions were sometimes temporarily lost and restored, not without making use of coercion.

Even if the US were immensely superior in the four aforementioned dimensions, Cuba (1959), Nicaragua (1979) and Grenada (1979) defied the hegemony of Washington at some point. The American response was either to invade or to support counter-revolutionary guerillas against the new regimes, just like South Africa did in its own periphery. In the long term, the American hegemony prevailed because the opponents were few and, when they were too radical, Washington could secure the cooperation of every other country in the region in isolating them. South Africa tried for a long time (1975-1989) to resist its decay, but opponents multiplied, built alliances against the hegemon and finally overthrew it from such status.

10. Economic recession, and the apparent impossibility of overthrowing FRELIMO in the shortterm, led Pretoria to the signing of the Nkomati Accord in March 1984 in order to end the support both countries were giving to rebel groups in each other's territory. Yet, while Mozambique acted in good faith by taking action against the ANC, South Africa bluntly cheated.

11. It has already been noted that Pretoria maintains different relations with countries that are highly dependent - like Botswana, Lesotho, Madagascar, Namibia and Swaziland -, those of medium dependence - Mozambique, Zambia and Zimbabwe - with one of relatively low dependence - Angola (Döpcke 1998, 136).

12. It is important to highlight that this pretended mandate 'was never agreed upon in any of the SADC meetings prior to the intervention' (Mahlakeng and Solomon 2013), giving rise to a series of controversies inside the institution and a fracture with other second-tier states - particularly Angola and Zimbabwe - that would become evident during the DRC crisis.

13. This threshold is a simple three-to-one relation between the first and the second regional powers. If the power of the former is more than three times that of the latter, then the system is said to be unipolar. If not, it is an indicator of bipolarity. 
14. Interview with Aguiar Mazula, former Defence Minister of Mozambique.

15. Zambia has consistently exported around $10 \%$ of what it imported from South Africa, while Zimbabwe shows a different trend, as its economic relations evolved from one of relative interdependence (40\%) in 2003 to a more hegemonic ideal type (8\%) in 2014.

\section{Acknowledgements}

This chapter benefitted from four months of fieldwork and some thirty in-depth interviews conducted in Southern Africa during 2015 on a trip funded by the European Union's ERASMUSMundus programme. I would like to thank Universidade Eduardo Mondlane (Maputo, Mozambique) for providing logistic support, and my wife, Natália Bueno Schenoni (the real area specialist), for her support, assistance and criticism.

\section{Disclosure statement}

No potential conflict of interest was reported by the author.

\section{Note on contributor}

Luis L. Schenoni is a PhD Student at the University of Notre Dame and a Doctoral Affiliate at the Kellogg Institute for International Studies. He has published extensively on realist approaches to Latin American foreign policy in journals such as Foreign Policy Analysis and Latin American Politics and Society. More recently he has extended that framework to Southern Africa in articles published in Strategic Analysis and Revista CIDOB, among others. He can be contacted at: Ischenon@nd.edu.

\section{References}

Ahwiring, F., and P. McGowan. 1998. "Partner of Hegemon: South Africa in Africa." Journal of Contemporary African Studies 16 (1/2): 165-195.

Alden, Christopher, and Maxi Schoeman. 2016. "Reconstructing South African Identity through Global Summitry." Global Summitry 1 (2): 187-204. ISSN 2058-7430.

Berman, E., and K. Sams. 2000. Peacekeeping in Africa: Capabilities and Culpabilities. New York: United Nations.

Bond, P. 2004. "The ANC's "Left Turn" \& South African Sub-Imperialism." Review of African Political Economy 31 (102): 599-616.

Brooks, S., and W. Wohlforth. 2008. World Out of Balance: International Relations and the Challenge of American Primacy. Princeton: Princeton University Press.

Burdette, M. M. 1984. "The Mines, Class Power and Foreign Policy in Zambia." Journal of Southern African Studies 10 (2): 198-218.

Burges, S. 2008. "Consensual Hegemony: Theorizing Brazilian Foreign Policy After the Cold War." International Relations 22 (1): 65-84.

Chanaiwa, D. 2010. "A África Austral." In História Geral da África: África desde 1935, edited by A. Mazrui, 295-334. Brasilia: UNESCO.

Cilliers, J. 1995. "Security and Transition in South Africa." Journal of Democracy 6 (4): 35-49.

Collier, D., and J. Mahon. 1993. "Conceptual "Stretching" Revisited: Adapting Categories in Comparative Analysis." American Political Science Review 87: 845-855.

Cox, R. 1983. "Gramsci, Hegemony and International Relations: An Essay in Method." Millennium: Journal of International Studies 12: 162-175.

Daniels, J., R. Southall, and S. Naidu. 2008. "The South Africans are Coming!" In The State of The Nation, edited by J. Daniels and R. Southall, 1-23. Pretoria: HSRC.

Davenport, R., and Ch Saunders. 2000. South Africa: A Modern History. New York: Saint Martin's Press.

Davies, R. 1985. "South African Strategy Towards Mozambique in the Post-Nkomati Period." Scandinavian Institute of African Studies Research Report 73: 1-72. 
Döpcke, Wolfgang. 1998. "Uma nova política exterior depois do apartheid? - Reflexões sobre as relações regionais da África do Sul, 1974 - 1998." Revista Brasileira de Politica Internacional 41 (1): 133-161.

Finnemore, M. 2009. "Legitimacy, Hypocrisy, and the Social Structure of Unipolarity: Why Being a Unipole Isn't All It's Cracked Up to Be." World Politics 61 (1): 58-85.

Flemes, D. 2009. "Regional Power South Africa: Co-Operative Hegemony Constrained by Historical Legacy." Journal of Contemporary African Studies 27 (2): 135-157.

Geldenhuys, D. 1984. The Diplomacy of Isolation: South African Foreign Policy Making. Johannesburg: Macmillan.

Gerring, J. 1999. "What Makes a Concept Good? A Criterial Framework for Understanding Concept Formation in the Social Sciences." Polity 31 (3): 357-393.

Gibb, R. 1998. "Southern Africa in Transition: Prospects and Problems Facing Regional Integration." The Journal of Modern African Studies 36 (2): 287-306.

Gilpin, R. 1981. War and Change in International Politics. Cambridge: Cambridge University Press.

Goertz, G. 2006. Social Science Concepts: A User's Guide. Princeton, NJ: Princeton University Press.

Grassi, S. 2013. "China and Africa, the 'Growth Continent'." Journal of Social Democracy 3: 27-32.

Grundy, K. W. 1979. Aspects of International Relations in Africa, 85-107. Pretoria: African Studies Programme. M. Delancey (org.).

Habib, A., and N. Selinyane. 2006. "Constraining the Unconstrained: Civil Society and South Africa's Hegmonic Obligations in Africa." In In Full Flight: South African Foreign Policy After Apatheid, edited by W. Carlnaes and P. Nel, 175-194. Mirand: Institute for Global Dialogue.

Hamill, J. 1998. "From Realism to Complex Interdependence? South Africa, Southern Africa and the Question of Security" International Relations 14 (3): 1-30.

Huntington, S. 1999. "The Lonely Superpower (US Military and Cultural Hegemony Resented by Other Powers)." Foreign Affairs 78 (2): 35-49.

Ikenberry, J., M. Mastanduno, and W. Wohlforth. 2009. "Unipolarity, State Behavior, and Systemic Consequences." World Politics 61 (1): 1-27.

Keohane, R. 1984. After Hegemony. Princeton: Princeton University Press.

Kibble, S., P. Goodison, and T. Balefi. 1995. "The Uneasy Triangle - South Africa, Southern Africa and Europe in the Post-Apartheid Era." International Relations 12 (4): 41-61.

Kindleberger, Ch. 1973. The World in Depression, 1929-1939. Berkeley: University of California Press. Krasner, S. 1976. "State Power and the Structure of International Trade." World Politics 28 (3): 317-347.

Krauthammer, Ch. 1990. "The Unipolar Moment." Foreign Affairs 70 (1): 23-33.

Lake, D. 1993. "Leadership, Hegemony, and the International Economy: Naked Emperor or Tattered Monarch with Potential?" International Studies Quarterly 37 (4): 459-489.

Landsberg, Ch. 2000. "South Africa and Nigeria: Hegemons or Strategic Partners?" Global Dialogue 5 (2): 22-24.

Landsberg, Ch. 2014. "The Concentric Circles of South Africa's Foreign Policy Under Jacob Zuma." India Quarterly: A Journal of International Affairs 70 (2): 153-172.

Lemke, D. 2002. Regions of War and Peace. Cambridge: Cambridge University Press.

Mahao, C. 2006. "The Power of Hegemonic Theory in Southern Africa: Why Lesotho Cannot Develop an Independent Foreign Policy." Master Thesis in International Relations., Rhodes University.

Mahlakeng, M., and H. Solomon. 2013. "Internal and External Political Dynamics Influencing Lesotho's Foreign Policy." Insight on Africa 5 (1): 35-53.

Makoa, F. 1999. "Foreign Military Intervention in Lesotho's Election Dispute: Whose Project?" Strategic Review of Southern Africa 21 (1): 66-87.

Martín, F. 2006. Militarist Peace in South America: Conditions for War and Peace. New York: Palgrave.

Martin, W. 2013. "South Africa and the "New Scramble for Africa': Imperialist, Sub-Imperialist, or Victim?" Agrarian Southern: Journal of Political Economy 2 (2): 161-188.

Masunungure, E., and S. Badza. 2010. "The Internationalization of the Zimbabwe Crisis: Multiple Actors, Competing Interests." Journal of Developing Societies 26 (2): 207-231.

Mearsheimer, J. 2001. The Tragedy of Great Power Politics. New York: Norton.

Meneses, F., and R. McNamara. 2014. "Parallel Diplomacy, Parallel War: The PIDE/DGS's Dealings with Rhodesia and South Africa, 1961-74." Journal of Contemporary History 49 (2): 366-389. 
Mills, G., and D. Williams. 2006. Seven Battles That Shaped South Africa. Cape Town: Tafelberg.

Mouron, F., F. Urdinez, and L. Schenoni. 2016. "Sin espacio para todos: China y la competencia por el sur." Revista CIDOB 114: 17-39.

Nathan, L. 2012. Community of Insecurity. London: Ashgate.

Pape, R. 2005. "Soft Balancing Against the United States." International Security 30 (1): 7-45.

Pisani, A. 1994. "South Africa and the Region." In From Pariah to Participant: South Africa's Evolving Foreign Policy, 1990-1994, G. Mills (org.), 52-69. Johannesburg: SAllA.

Poku, N. 2001. Regionalization and Security in Southern Africa. Basingstoke: Palgrave.

Ross, R. 1999. A Concise History of South Africa. Cambridge: Cambridge University Press.

Rotberg, R. I. 1985. South Africa and its Neighbors. Regional Security and Self-Interest, 1-12. Lexinton: Lexington Books. R. I. Rotberg (coord.).

SADC. 2013. "Communiqué of the 33rd Summit of SADC Heads of State and Government." http:// www.sadc.int/files/5513/7691/9196/COMMUNIQUE 18_August_2013.pdf.

Sartori, G. 1970. "Concept Misformation in Comparative Politics." American Political Science Review 64 (4): 1033-1053.

Saunders, Ch, and N. Southey. 1998. A Dictionary of South African History. Cape Town: David Philip.

Schenoni, L. 2015. "The Brazilian Rise and the Elusive South American Balance." GIGA Working Paper Series 267: 1-23.

Schenoni, L. 2016. "Regional Power Transitions: Lessons from the Southern Cone." GIGA Working Paper Series 293: 1-33.

Schenoni, L. 2017. "Subsystemic Unipolarities? Power Distribution and State Behaviour in South America and Southern Africa." Strategic Analysis 41 (1): 74-86.

Schenoni, L., and E. Actis. 2014. "Argentina y Brasil: una unipolaridad regional con sesgo hegemónico." Revista SAAP 8 (1): 207-235.

Schoeman, M. 2003. "South Africa as an Emerging Middle Power: 1994-2003." In State of the Nation: South Africa 2003-2004, edited by A. Daniel, A. Habib and R. Southall, 349-367. Cape Town: HSRC.

Schweller, R. 2004. "Unanswered Threats: A Neoclassical Realist Theory of Underbalancing." International Security 29 (2): 159-201.

Seabra, P., and P. Gorjao. 2011. "Intertwined Paths: Portugal and Rising Angola." SAllA Occasional Paper 89: 1-28.

Shaw, T. 2015. "African Agency? Africa, South Africa and the BRICS." International Politics 52 (2): 255268.

Singer, D., S. Bremer, and J. Stuckey. 1972. "Capability Distribution, Uncertainty, and Major Power War, 1820-1965." In Peace, War, and Numbers, edited by Bruce Russett, 19-48. Beverly Hills: Sage.

Söderbaum, Fredrik. 2004. The Political Economy of Regionalism. The Case of Southern Africa. London: Palgrave Macmillan.

Strange, S. 1988. States and Markets. London: Printer.

Taliaferro, J. 2006. "State Building for Future Wars: Neoclassic Realism and the Resource-Extractive State." Security Studies 15 (3): 464-495.

Taylor, I. 2011. "South African 'Imperialism' in a Region Lacking Regionalism: A Critique." Third World Quarterly 32 (7): 1233-1253.

Thompson, C. B. 1988. Zimbabwe's Prospects. Issues of Race, State and Capital in Southern Africa, 238256. London: MacMillan. C. Stoneman, (org.).

Vale, P. 1996. "Regional Security in Southern Africa." Alternatives: Global, Local, Political 21: 363-391. Vale, P. 2003. Security and Politics in South Africa: The Regional Dimension. Cape Town: UCT Press.

Van Wyk, J. 1997. "South Africa in Southern Africa: The Case for Benign Hegemony." Global Dialogue 2 (3): 10-12.

Walt, S. 2009. "Alliances in a Unipolar World." World Politics 61 (1): 86-120.

Waltz, K. 1979. Theory of International Politics. New York: McGraw Hill.

Wilkinson, D. 1999. “Unipolarity Without Hegemony." International Studies Review 1 (2): 141-172.

Wohlforth, W. 1999. "The Stability of a Unipolar World." International Security 24 (1): 5-41.

Zakaria, F. 1998. From Wealth to Power: The Unusual Origins of America's World Role. Princeton: Princeton University Press. 